\title{
Expression and Localization of Glucose Transporters in Rodent Submandibular Salivary Glands
}

\author{
Sibel Cetik ${ }^{a}$ Emeline Hupkens ${ }^{a}$ Willy J. Malaisse ${ }^{a}$ Abdullah Senera,c \\ Iuliana Ristea Popescua,b,c \\ Laboratories of a Experimental Hormonology and ${ }^{b} H i s t o l o g y$, Neuroanatomy and Neuropathology, \\ Université Libre de Bruxelles, Brussels, Belgium; 'These co-authors have contributed equally to this \\ work
}

\section{Key Words}

GLUT1 • GLUT2 • GLUT4 • SGLT1 • Submandibular salivary gland • Glucose transporters • Ductal cell

\begin{abstract}
Background/Aim: The submandibular gland is one of the three major salivary glands, producing a mixed secretion; this saliva is hypotonic compared to plasma. It also secretes glucose, but the mechanisms responsible for this process are poorly understood. Our study addressed the question whether glucose transporters are expressed and how are they localized within specific rodent submandibular cells, in order to estimate a possible implication in salivary glucose disposal. Methods: Immunohistochemistry, RT-qPCR and Western blotting were performed to determine the presence/localization of glucose transporters in rodent submandibular glands. Results: GLUT4 was identified in the submandibular salivary gland at both mRNA and protein level. The immunohistochemical analysis revealed its localization preponderantly in the ductal cells of the gland, near to the basolateral. SGLT1 and GLUT1 were highly expressed in submandibular tissues in both acinar and ductal cells, but not GLUT2. These results were confirmed by RT-qPCR. It was also documented that insulin stimulates the net uptake of D-glucose by ductal rings prepared from submandibulary salivary glands, the relative magnitude of such an enhancing action being comparable to that found in hemidiaphragms. Conclusion: At least three major glucose transporters are expressed in the rodent submandibular glands, of which GLUT4 is specifically localized near the basolateral side of ductal structures. This points-out its possible role in regulating glucose uptake from the bloodstream, most likely to sustain ductal cellular metabolism.
\end{abstract}

Copyright $@ 2014$ S. Karger AG, Basel 


\section{Introduction}

Salivary glands are responsible for the secretion of D-glucose in saliva. The molecular mechanisms involved in the uptake of extracellular D-glucose by salivary cells and the excretion of the hexose by salivary glands remain a matter of debate. They may differ in distinct salivary glands. For instance, Mangos et al. [1] reported that, in the rat parotid gland, the ratio between the concentration of D-glucose in the intracellular parotid water and plasma parotid water reached, within one hour after the intravenous injection of ${ }^{14} \mathrm{C}$-labelled D-glucose or 3-0-methyl-D-glucose, an equilibrium value close to unity. Yet, the saliva water-to-plasma glucose concentration ratio in rat parotid saliva did not exceed 0.35 and progressively decreased as a function of the salivary flow rates. These findings suggest that a transport or permeability barrier exists on the luminal side as well as contra-luminal side of the cells, lining the acini and intercalated ducts of the parotid. In the same study [1], it was documented that the intercalated duct fluid-to-plasma water ratio for ${ }^{14} \mathrm{C}$-labelled D-glucose as measured on the hilar opening of the main duct, was virtually identical to that of the saliva water-to-plasma ratio for the radioactive hexose as measured at the distal opening at the parotid duct, suggesting that the excretory ducts of the parotid gland are impermeable to both water and glucose.

In the light of experiments conducted in the submandibular and sublingual glands, however, Takai et al. [2] proposed that the glucose passes through a paracellular route from blood to saliva in these glands. The permeability of this paracellular pathway appeared higher in the sublingual gland than in the submandibular gland. Moreover, both the micro-infusion of ouabain and the intra-ductal injection of either phlorizin or diethylstilbestrol, which, in the small intestine inhibit the movement of glucose from lumen to basal sites, were found to increase the glucose concentration in submandibular saliva, indicating a process of glucose reabsorption in theses glands, possibly located in the striated duct of the rat submandibular gland. In the sublingual gland, however, a lack of effect of the above mentioned inhibitors on salivary glucose concentration suggested the absence of a glucose re-absorption mechanism in this gland. More recent studies deal with the expression, immunolocalization, aminoacid sequence and possible role of $\mathrm{Na}^{+}$-dependent D-glucose symporter (SGLT1) in salivary glands [3-7]. This transporter was first localized at the basolateral level of acinar parotid cells. Investigations conducted in animal models of diabetes mellitus indicated a decreased content of SGLT1 in parotid and submandibular salivary glands [8]. The aim of the present study was to explore the expression and localization of glucose transporters in rodent submandibular glands, as a first step to elucidate their implication in the regulation of salivary glucose disposal.

\section{Materials and Methods}

\section{Tissues}

Animal housing and experimental procedures were accomplished in accordance with the ethical regulations stated by the Ethical Board of the Université Libre de Bruxelles and the European Communities Council Directives (86/609/EEC and 87-848/EEC). Wistar female and male rats (Charles River, Belgium) aged 12-13 weeks ( $n=3$ for each sex) were overnight fasted and then sacrificed under deep i.p. anesthesia induced by a combination of ketamine $(60 \mathrm{mg} / \mathrm{kg})$ and xylazine $(7.5 \mathrm{mg} / \mathrm{kg})$. Tissues were removed and conserved overnight in formaline $10 \%$ or paraformaldehyde-PBS $4 \%$ prior to paraffin processing or in liquid nitrogen and stored at $-80^{\circ} \mathrm{C}$ prior to RNA and protein extraction. For mouse tissues, female and male $\mathrm{C} 57 \mathrm{Bl} / 6$ mice ( $\mathrm{n}=3$ for each sex) were sacrificed by cervical dislocation and tissues were recuperated and processed as described for rats.

Immunostaining procedures

Paraffin-embedded tissues were sectioned on a classical microtome (5-7 $\mu \mathrm{m}$ thickness) and transversal sections collected on Superfrost Plus coverslips pre-treated with poly-L-lysin. 
Table 1. Sequence of rat primers used in qPCR analysis

\begin{tabular}{lll}
\hline Gene name & Forward $\left(5^{\prime}-3^{\prime}\right)$ & Reverse $\left(5^{\prime}-3^{\prime}\right)$ \\
\hline Cyclophilin & GCATACGGGTCCTGGCATCTTGTCC & ATGGTGATCTTCTTGCTGGTCTTGC \\
GLUT 1 & ACTCCATGCTGATGATGAACC & CACGCCACAGTACAGTCCAAT \\
GLUT 2 & CTTGGTTCATGGTTGCTGAAT & GAAGTCCGCAATGTACTGGAA \\
GLUT 4 & CTCTCAGGCATCAATGCTGTT & GAGACCAACGTGAAGACGGTA \\
SGLT1 & CATGATTGCAGGAAGGTTGTT & GGTAACTGGTGATGGACTGGA \\
\hline
\end{tabular}

For immununostaining, sections were dewaxed, rehydrated, permeabilized in TBS and blocked with $10 \%$ normal goat serum for one hour at room temperature, preceded by microwave antigen retrieval in citrate buffer $10 \mathrm{mM}(\mathrm{pH} \mathrm{6)}$. Sections were incubated with the primary antibody diluted in TBS with 1\% normal goat serum, overnight at $4^{\circ} \mathrm{C}$.

In double immunofluorescence staining, the following primary antibodies were used: rabbitanti-GLUT4 (Millipore, Massachusetts, USA) 1:100; rabbit anti-GLUT1 (Millipore) 1:100; rabbit anti-SGLT1 (Millipore) 1:100; mouse anti- $\mathrm{Na}^{+} / \mathrm{K}^{+}$-ATPase (Millipore), 1:200. The secondary antibodies were goat anti-rabbit conjugated to Alexa594 (Invitrogen, California, USA) 1:100 and goat anti-mouse conjugated to Alexa488 (Cell Signalling, Massachusetts, USA) 1:200. For GLUT1 staining in immunofluorescence, an amplification procedure based on tyramid-FITC staining (Perkin Elmer, Waltham, Massachusetts, USA) was used as described by manufacturer instructions. In DAB staining experiments, the primary antibodies mentioned above and the rabbit anti-GLUT2 antibody (Santa Cruz Biotechnology, California, USA) were used at 1:500 dilution and detected with a secondary biotinylated goat anti-rabbit IgG (Vector Lab., Southfield, Michigan, USA) 1:300, followed by treatment with avidin-biotin-peroxidase (Vector Lab.) and diaminobenzidine (DAB; Dako, Glostrup, Denmark), with hematoxylin counterstaining. In immunostaining experiments using the mouse monoclonal antibody anti-Glut4 (AbD Serotec; 1:500), tissues were fixed overnight in PAF 4\% before paraffin embedding. The goat anti-mouse secondary antibody conjugated with horseradish peroxidase (Molecular Probes; 1:50) was used as secondary antibody. The diaminobenzidine reaction was used for revelation. In all experiments, negative controls were obtained by omitting the primary antibody. Sections were examined using the Axioplan microscope (Zeiss) or a Leica LCC50 system.

\section{RNA extraction and RT- $q P C R$}

Tissues were harvested in Purezol (BioRad, UK) and total RNA was extracted according to the producer specifications. The cDNA was synthetized in a BioRad Thermocycler by using a High Capacity Reverse Transcription kit (Applied BioSystem, Carlsbad, California, USA) according to the manufacturer instructions. mRNA levels of the analysed genes were quantified by real-time quantitative PCR using the Mesagreen Master Mix kit (Eurogentec, Seraing, Belgium) based on the Sybr Green detection system, using the specific primers (Eurogentec Seraing, Belgium) (Table 1).

mRNA expression levels were normalized to the house keeping gene Cyclophilin and quantified by the $\Delta \Delta$ Ct method.

\section{Western blotting}

Tissue samples were harvested on ice by homogenising with RIPA lysis buffer (Trizma- pH7.4, 50mM, $\mathrm{NaCl} 150 \mathrm{mM}$, NP40 10\%, sodium deoxycholate 0.25\%) supplemented with protease inhibitor cocktail Complete ${ }^{\circledR}$ (Roche Diagnostics, Basel, Switzerland) and phosphatase inhibitor cocktail 2 (Sigma). $40 \mu \mathrm{g}$ of total protein extract were resolved in SDS-PAGE gels and transferred to a nitrocellulose membrane (Millipore) for immunoblotting (Bio-Rad system). After overnight blocking in 5\% milk in Tris-HCl buffered saline- $0.1 \%$ Tween, the membrane was incubated overnight with the polyclonal anti-GLUT4 antibody (Millipore) 1:500 and then with the corresponding secondary antibody (anti-rabbit IgG, 1:5000; Amersham Biosciences, Piscataway, New Jersey, USA) for 1 hour at room temperature. The immunoreactive bands were visualised using the ECL chemiluminescence detection reagent (Amersham Biosciences). 


\begin{tabular}{|c|c|}
\hline Cellular Phys & Cell Physiol Biochem 2014;33:1149-1161 \\
\hline and Biochemistry & $\begin{array}{l}\text { DOI: 10.1159/000358684 } \\
\text { Published online: April } 11,2014\end{array}$ \\
\hline
\end{tabular}

Fig. 1. Assessment of GLUT1 glucose transporter in the submandibular salivary gland of rat and mouse. A: Immunoreactivity of GLUT1 in the basolateral membrane of striated ducts (SD), granular convoluted tubules (GCT) and mucous acini (MA) in a female submandibular gland; B: GLUT1 localization in a submandibular of male rat; note the strong reactivity of GLUT1 in the basolateral membrane of interlobular excretory ducts (arrow); C: GLUT1 localization in a submandibular of mouse; D: GLUT1 staining in the parotid gland (positive control); E: No immunoreactivity of the secondary antibody in mouse submandibular gland (negative control); F and G: Sub-cellular localization of GLUT1 in the submandibular salivary gland of a female rat, revealed by immunofluorescence; F: General appraisal of GLUT1 distribution in the ducts and GCT (arrows and arrowheads, respectively) and at a lesser extent in the acini; G: Detail of two striated excretory ducts stained with anti-GLUT1 by the amplification with Tyramide. Nuclei were counterstained with Hematoxyline (blue). Scale bar $=50 \mu \mathrm{m}(\mathrm{A}, \mathrm{C}, \mathrm{D}, \mathrm{G})$ and $100 \mu \mathrm{m}(\mathrm{B}, \mathrm{F})$.

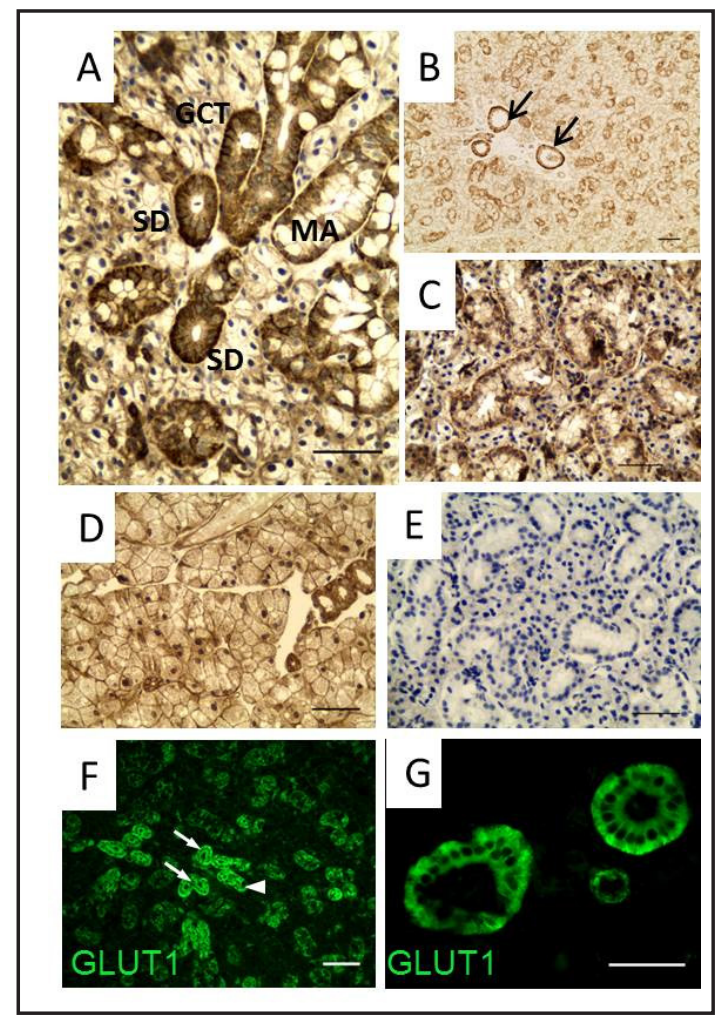

\section{Metabolic studies}

The isolation of ductal cells and the preparation of hemidiaphragms and of ductal rings were described in the cited references [9-11]. For the metabolic studies, isolated ductal cells, hemidiaphragms and ductal rings were suspended in a bicarbonate-buffered medium [12] containing a Hepes-NaOH buffer $(20 \mathrm{mM}, \mathrm{pH} 7.4)$ and BSA $(1.0 \mathrm{mg} / \mathrm{ml})$. For the utilisation of D-glucose, hemidiaphragms and ductal ring were incubated in bicarbonate-buffered media containing a Hepes-NaOH buffer (20 mM, pH 7.4), BSA (1.0 $\mathrm{mg} / \mathrm{ml}$ ) and D-glucose $5.6 \mathrm{mM}$. After 30 to $180 \mathrm{~min}$ incubation, an aliquot of incubation medium was taken out in order to measure the remaining D-glucose concentration by the hexokinase method $[13,14]$. The apparent distribution spaces of ${ }^{3} \mathrm{HOH}, \mathrm{L}-\left[1-{ }^{-14} \mathrm{C}\right]$ glucose and D-[U- $\left.-{ }^{14} \mathrm{C}\right]$ glucose were measured according to a procedure previously defined [15]. The method used to measure D-[5- $\left.{ }^{3} \mathrm{H}\right]$ glucose utilization and D-[U- $\left.-{ }^{14} \mathrm{C}\right]$ glucose oxidation were previously described [16].

\section{Statistics}

Results are expressed as means \pm SEM, as indicated in the figure legend. The statistical significance of differences was calculated with GraphPad Prism ${ }^{\circledR} 4.0$ (GraphPad Software Inc., San Diego, CA). A p value under 0.05 was considered statistically significant.

\section{Results}

Immunohistochemistry

Immunohistochemical detection of glucose transporters in the rodent submandibular tissues revealed differences in their expression and localization.

GLUT1 immunoreactivity in rat and mouse submandibular glands showed a strong staining preponderantly at the basolateral membrane of all ductal structures and to a lower extent in the secretory units (Fig. $1 \mathrm{~A}-\mathrm{E}$ ). A positive signal was also detected in the cytoplasmic compartment. These results were also confirmed by immunofluorescence and showed the localization of GLUT1 transporter preponderantly toward the basolateral pole of striated and interlobular ducts, with a lesser intensity in the granular convoluted tubules (GCT) (Fig. 1 F, G). 


\begin{tabular}{|c|c|c|}
\hline Cellular Physiology & Cell Physiol Biochem 2014;33:1149-1161 & \\
\hline and Biochemistry & $\begin{array}{l}\text { DoI: 10.1159/000358684 } \\
\text { Published online: April II, } 2014\end{array}$ & $\begin{array}{l}\text { O } 2014 \text { S. Karger AG, Basel } \\
\text { www.karger.com/cpb }\end{array}$ \\
\hline
\end{tabular}

Fig. 2. General appraisal of a female rat submandibular gland immunostained with a polyclonal antiGLUT2 antibody. A: Anti-GLUT2 staining in the rat submandibular gland with weak reactivity; C: GLUT2 staining of the rat hepatic tissue (positive

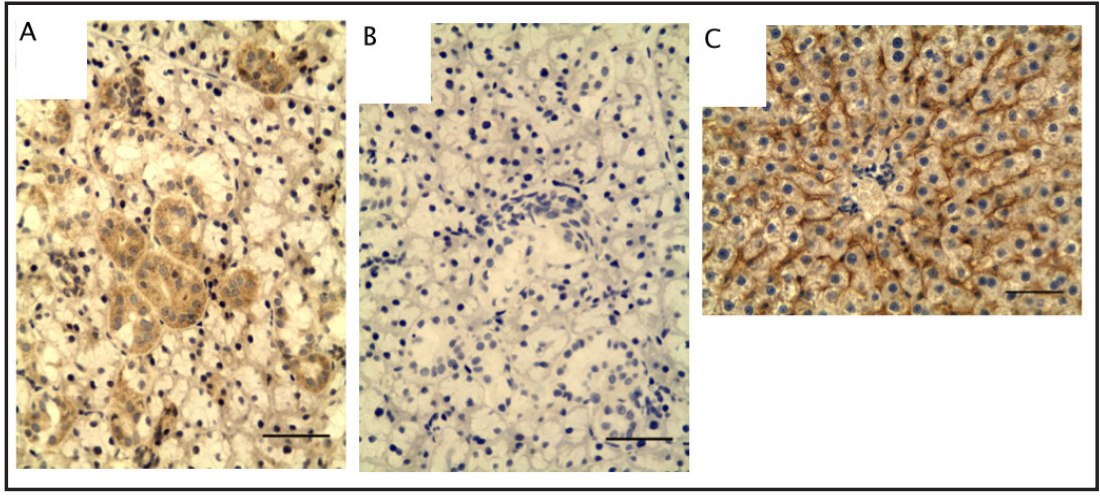
control); B: No immunoreactivity of the secondary antibody in the rat submandibular gland. Nuclei were counterstained with Hematoxyline (blue). Scale bar $=100 \mu \mathrm{m}$.

Fig. 3. GLUT4 immunodetection in rat and mouse submandibular gland with a rabbit polyclonal anti-GLUT4 antibody (Millipore). A: Positive immunoreaction of GLUT4 in the striated ductal cells (SD), granular convoluted tubules (GCT) and intercalated ducts (ID) but not in the acinar cells of the female submandibular gland. The arrow indicates a pillar cell; B and C: Representative images of GLUT4 immunoreactivity in and nearby the basolateral membrane of striated ducts; C: No apical localization was identified in this duct (arrow); D: GLUT4 immunodetection in the submandibular of a male rat; E: General appraisal of mouse submandibular gland immunostained for GLUT4 reveals a similar staining as in rat tissue; F: GLUT4 immunoreactivity of rat skeletal muscle (positive control) G and H: GLUT4 immuofluores-

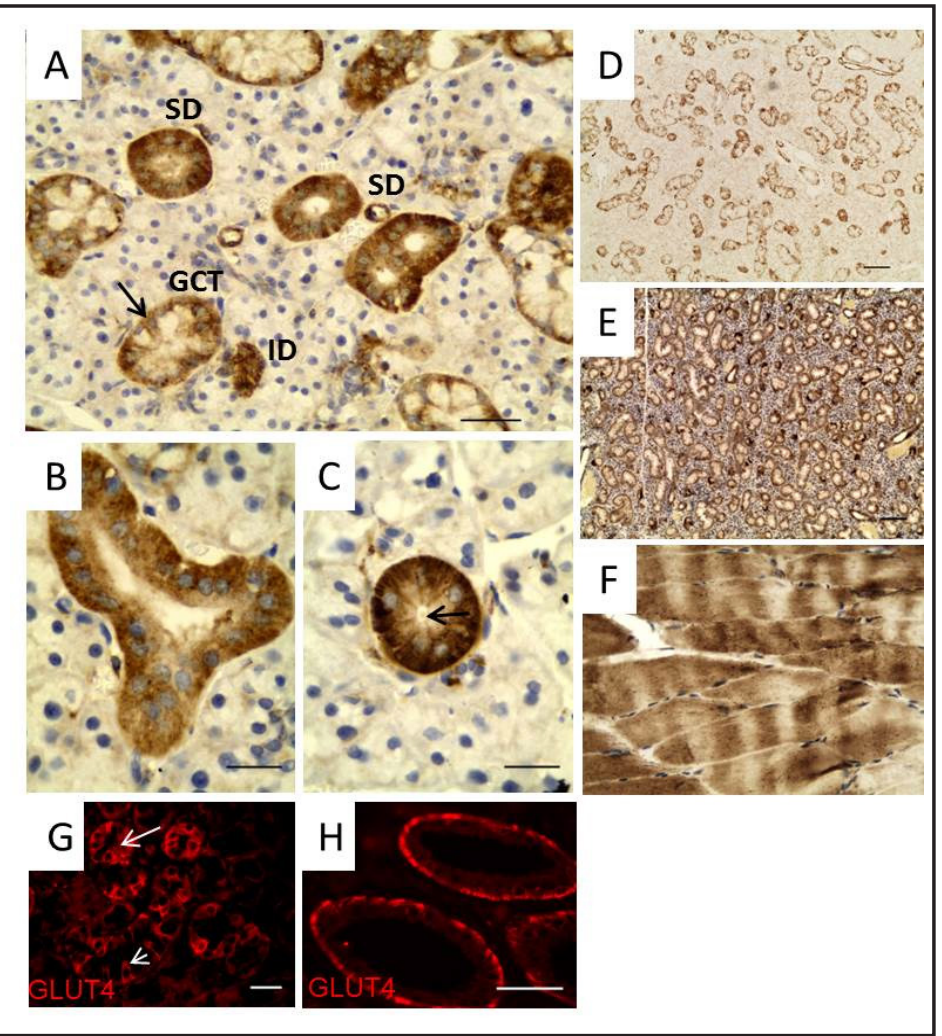
cence in rat submandibular gland; G: Basolateral localization of GLUT4 in striated ducts (arrow) and GCT (arrowhead); H: Preponderant basal localization of GLUT4 in the interlobular excretory ducts; Nuclei were counterstained with Hematoxyline (A-C, E, F). Scale bar $=20 \mu \mathrm{m}(B, C)$. Scale bar $=50 \mu \mathrm{m}(A, F, G, H)$. Scale bar $=100 \mu \mathrm{m}(\mathrm{D}, \mathrm{E})$.

A weak GLUT2 immunoreactivity was detected in the ductal structures of rat submandibular glands compared to the positive control tissue (Fig. 2).

The insulin-dependent glucose transporter GLUT4 was detected in different anatomic substructures of the submandibular gland of rat and mouse with a medium to strong intensity, by both anti-GLUT4 antibodies (Fig. 3 and Fig. 4). Thus, in both rat and mouse, a strong GLUT4 immunoreactivity was detected in the basolateral membrane and its adjacent 
Fig. 4. Immunodetection of GLUT4 transporter in rat tissues with a mouse monoclonal anti-GLUT4 antibody (AbD Serotec). Negative controls were obtained in striated muscle (A) and submandibular gland (E) by omission of the primary antibody. The skeletal muscle (B) and the the submandibular ductal structures (D, arrows F) were positively stained for GLUT4 while the liver (C) was negative. Nuclei were counterstained with Hematoxyline. Scale bar $=100 \mu \mathrm{m}$ (A-D). Scale bar $=25 \mu \mathrm{m}$ (E, F).
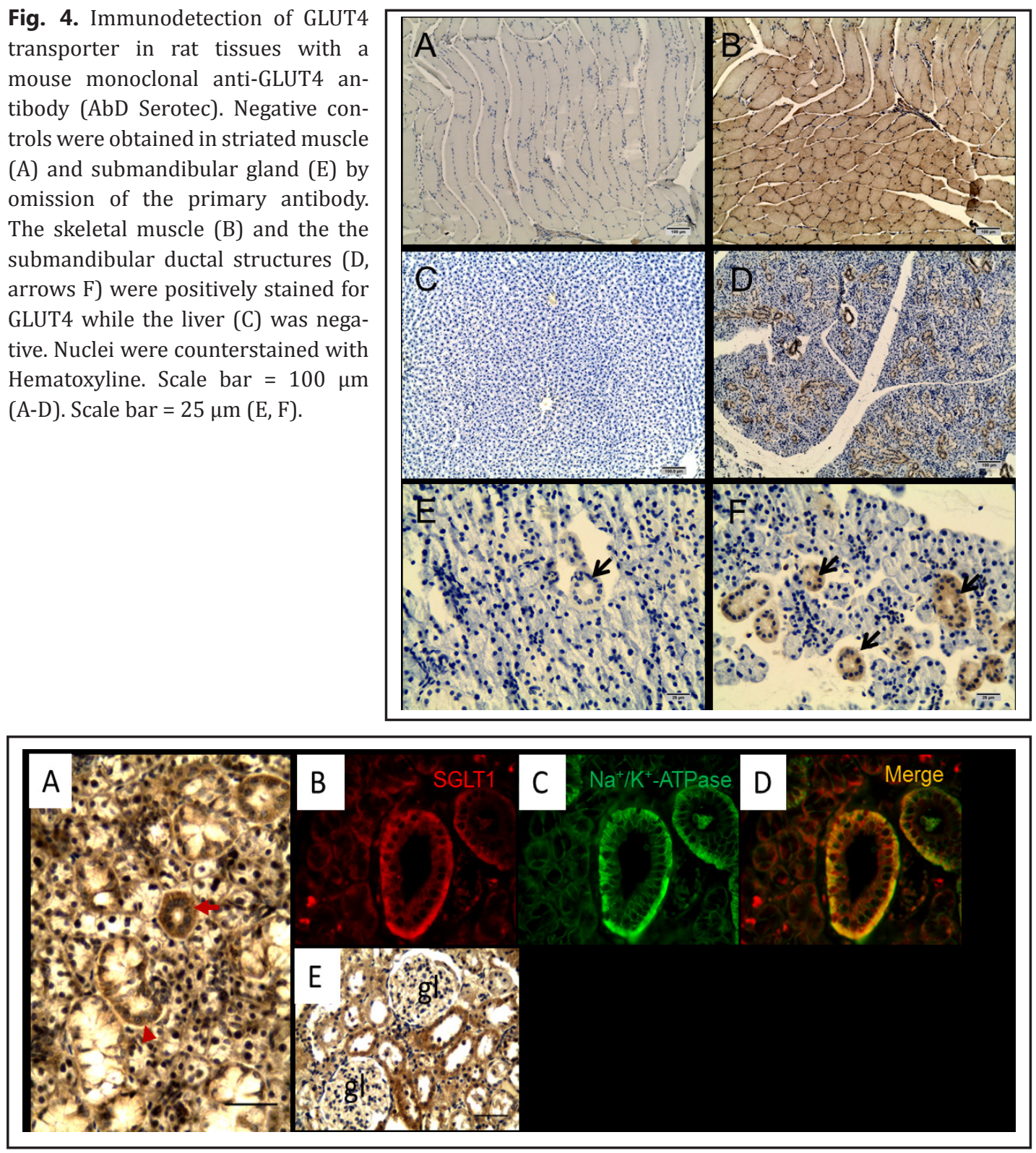

Fig. 5. Positive immunoreactivity of the $\mathrm{Na}^{+} /$Glucose co-transporter SGLT1 in the basolateral membrane of ducts (arrow) and GCT (arrowheads) of rat (A). B, C and D: SGLT1 co-localizes with $\mathrm{Na}^{+} / \mathrm{K}^{+}$-ATPase in the basolateral membrane of rat striated ductal cells; E: SGLT1 staining of rat kidney reveals the immunoreactivity of renal tubules but not of the glomeruli (gl). Nuclei were counterstained with Hematoxyline. Scale bar $=50 \mu \mathrm{m}$.

cytoplasmic compartment, but not or to a much lesser extent to the apical pole, of GCT, striated excretory and intercalated ducts (Fig. 3 A-E, G). In larger interlobular ducts, GLUT4 was detected to be accumulated preponderantly in the basal membrane of ductal cells (Fig. $3 \mathrm{H}$ ). GLUT4 was also detected in isolated ductal cells (data not shown). GLUT4 was not detected in the acinar cells.

A strong SGLT1 immunoreactivity was observed in the basolateral membrane of the acinar and ductal cells of rat and mouse submandibular glands but also in the cytoplasm (Fig. $5 \mathrm{~A}$ ). The apical staining was absent in these structures. SGLT1 transporter co-localized with the $\mathrm{Na}^{+} / \mathrm{K}^{+}$-ATPase on the basolateral membrane of striated ductal cells (Fig. 5 B-D). 
A

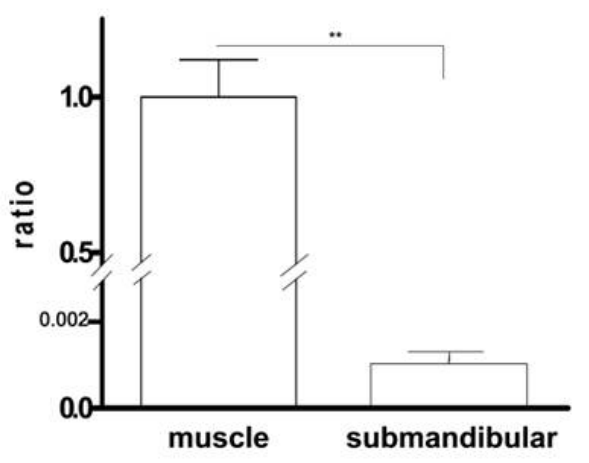

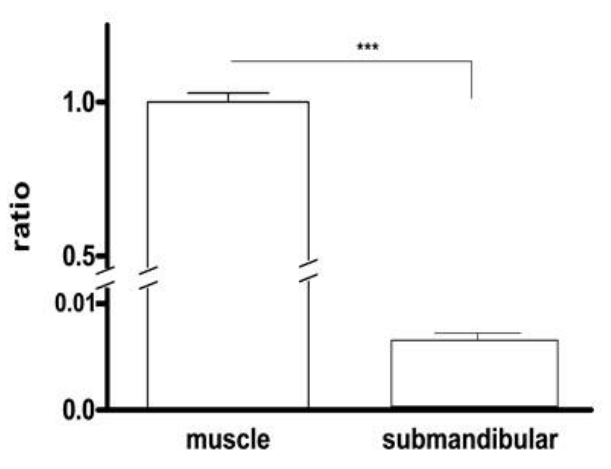

B

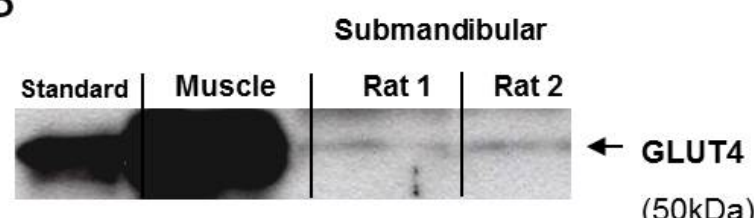

Fig. 6. Comparative expression of GLUT4 mRNA in submandibular salivary glands of female and male rats vs. muscle. A: Comparative mRNA expression of GLUT4 in the submandibular gland versus muscle (positive control) in female (left; $\mathrm{p}<0.01$ ) and male (right; $\mathrm{p}<0.001$ ) rats. Cyclophilin was used as housekeeping gene. Results are expressed as fold change $( \pm \mathrm{SEM}, \mathrm{n}=3$ ) compared to the muscle value set at 1 ; B: GLUT4 detection by immunoblotting revealed a $50 \mathrm{kDa}$ band in the protein extract of the whole submandibular gland of two rats. Muscle total protein extract was used as positive control.

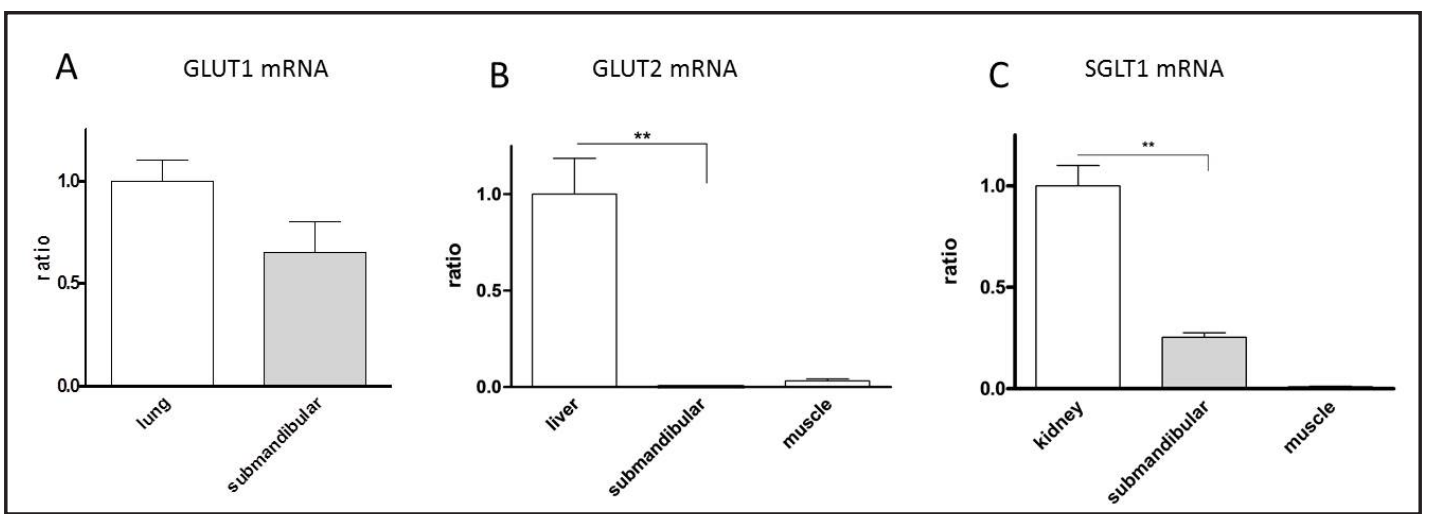

Fig. 7. Comparative mRNA expressions of GLUT1, GLUT2 and SGLT1 in rat submandibular salivary gland. A: "Comparative mRNA expression of GLUT1 in submandibular gland versus lung (positive control), in female rats ( $>>0.05)$; B: Comparative mRNA expression of GLUT2 in female rat submandibular gland versus liver (positive control) and muscle $(\mathrm{n}=3)(\mathrm{p}<0.01)$; C: Comparative mRNA expression of SGLT1 in submandibular gland versus kidney (positive control) and muscle (negative control), from female rats $(\mathrm{p}<0.01)$. Cyclophilin was used as housekeeping gene. Results are expressed as fold change ( \pm SEM, $n=3$ ) compared to the tissue used as positive control whose value was set at 1 .

\section{RT-qPCR and Western Blotting}

Expression of GLUT1, GLUT2, GLUT4 and SGLT1 transporters was also analyzed at the mRNA level in the submandibular salivary glands of rats (Fig. 6 and Fig. 7). Even if much less expressed than in the skeletal muscle, the master tissue for GLUT4 expression (average Ct value $=20$ ), GLUT4 mRNA was detected in the whole submandibular salivary tissue with 
an average Ct value of 29.5 for female rats and 27 for male rats (Fig. 6 A). GLUT4 detection by immunoblotting confirmed the presence of the corresponding $50 \mathrm{kDa}$ protein band in the total protein extract of female rat submandibular tissue (Fig. 6B). GLUT1 and SGLT1, but not GLUT2 transcripts were also present in the submandibular glands in rats (Fig. 7). Submandibular GLUT1 mRNA expression was similar to that found in lungs, considered as positive control (Fig. 7 A). GLUT2 mRNA expression in submandibular gland was not detected (Fig. 7 B). The transcription of SGLT1 gene was quantified at $\sim 1 / 4$ of that in the kidney (Fig. 7 C).

\section{Effect of insulin on glucose uptake by ductal rings of submaxillary salivary glands}

For the purpose of comparison with the results recorded in ductal rings of the submaxillary salivary gland, the effect of insulin upon D-glucose uptake was first examined in rat hemidiaphragms. As previously recommended [10], the uptake of D-glucose was expressed relative to the surface of the hemidiaphragms, taken as the square of the cubic root of their wet weight. In a first set of experiments, the hemidiaphragms were incubated up to $120 \mathrm{~min}$ in the presence of $5.6 \mathrm{mM} \mathrm{D}$-glucose at increasing concentrations of insulin (zero, $60 \mu \mathrm{U} / \mathrm{ml}, 3.0 \mathrm{mU} / \mathrm{ml}$ and $10.0 \mathrm{mU} / \mathrm{ml}$ ), the two hemidiaphragms from the same rat being incubated either in the absence versus presence of $10.0 \mathrm{mU} / \mathrm{ml}$ insulin or in the presence of $60 \mu \mathrm{U} / \mathrm{ml}$ versus $3.0 \mathrm{mU} / \mathrm{ml}$ insulin. In all cases, there was a close correlation between the net uptake of D-glucose and the length of incubation (30, 60, 90 and $120 \mathrm{~min})$, with an overall mean value for the correlation coefficients of $0.970 \pm 0.011(n=8 ; p<0.001)$. At the lowest concentration of insulin $(60 \mu \mathrm{U} / \mathrm{ml})$, the net uptake of D-glucose averaged $136.8 \pm 17.6 \%(\mathrm{n}=8 ; \mathrm{p}<0.08)$ of the corresponding basal value (no insulin) found at the same time within the same experiment, and represented only $77.2 \pm 6.5 \%(n=8 ; p<0.01)$ of the paired measurement recorded at the same time and within the same experiment in hemidiaphragms exposed to $3.0 \mathrm{mU} / \mathrm{ml}$ insulin. Covariance analysis indicated that, at the 60 $\mu \mathrm{U} / \mathrm{ml}$ concentration, insulin already increased significantly above basal value (no insulin) the slope of the regression line between net D-glucose uptake and incubation length $(\mathrm{F}=$ 6.819; $\mathrm{f}=1,12 ; \mathrm{p}<0.025)$. The enhancing action of insulin upon $\mathrm{D}$-glucose uptake was not significantly different at insulin concentrations of either $3.0 \mathrm{mU} / \mathrm{ml}$ or $10.0 \mathrm{mU} / \mathrm{ml}$, the slope of the regression line between D-glucose uptake and incubation length averaging at $3.0 \mathrm{mU} / \mathrm{ml} 88.4 \pm 6.6 \%(\mathrm{n}=2)$ of the mean corresponding value observed within the same experiment in the presence of $10.0 \mathrm{mU} / \mathrm{ml}$ insulin. Relative to the corresponding basal value (no insulin) found within the same experiment, the slopes of the regression lines between D-glucose uptake and incubation time yielded at the high concentrations of insulin (3.0 and $10.0 \mathrm{mU} / \mathrm{ml}$ ) an overall mean value of $154.2 \pm 10.0 \%$ ( $\mathrm{n}=4 ; \mathrm{p}<0.02$ versus unity). In the light of these findings, a second set of experiments was conducted at the same concentration of D-glucose $(5.6 \mathrm{mM})$ over the same incubation time $(30,60,90$ and $120 \mathrm{~min})$ in the absence or presence of $10.0 \mathrm{mU} / \mathrm{ml}$ insulin. As illustrated in Fig. 8 (left panel), over 30 to $120 \mathrm{~min}$ incubation, the uptake of D-glucose averaged in the presence of insulin $136.6 \pm 7.1 \%$ (n = $32 ; \mathrm{p}<0.001$ ) of the mean paired basal value (no insulin) recorded at the same time in the contralateral hemidiaphragm. The latter percentage was not significantly different $(>0.6)$ from that found, under the same experimental conditions in the first set of experiments, i.e. $144.4 \pm 18.5 \%(n=8)$. Whether in the absence or presence of insulin, the uptake of D-glucose was not strictly proportional to the length of incubation, the relationship between these two variables displaying an exponential pattern (Fig. 8, left panel). The difference between the estimated maximal values and mean experimental results indeed yielded straight lines in semi-logarithmic coordinates (Fig. 8, right panel). Covariance analysis confirmed that the slopes of the two regression lines illustrated in Fig. 8 (right panel) were virtually identical, whilst their elevation was vastly different $(F=84.5 ; \mathrm{f}=1,7 ; \mathrm{p}<0.005)$.

In a first set of experiments conducted in isolated acinar or ductal cells prepared from submandibular salivary glands and incubated for $20 \mathrm{~min}$, the paired ratio between the distribution space of $\mathrm{D}-\left[\mathrm{U}-{ }^{14} \mathrm{C}\right]$ glucose $(8.3 \mathrm{mM})$ and that of ${ }^{3} \mathrm{HOH}$ was not affected significantly ( $p>0.31$ or more) when either the acinar or ductal cells were exposed to 
Fig. 8. Time course for the uptake of D-glucose by rat hemidiaphragms incubated in the presence of $5.6 \mathrm{mM}$ Dglucose and either absence (open circles) or presence (closed circles) of insulin (10 $\mathrm{mU} / \mathrm{ml})$. Mean values $( \pm \mathrm{SEM})$ refer to 8 individual measurements (left panel). The right panel illustrates in semi-logarithmic coordinates the difference between estimated maximal values and mean experimental results, the dotted line (no insulin) and solid line (insulin present) corresponding to the regression lines.

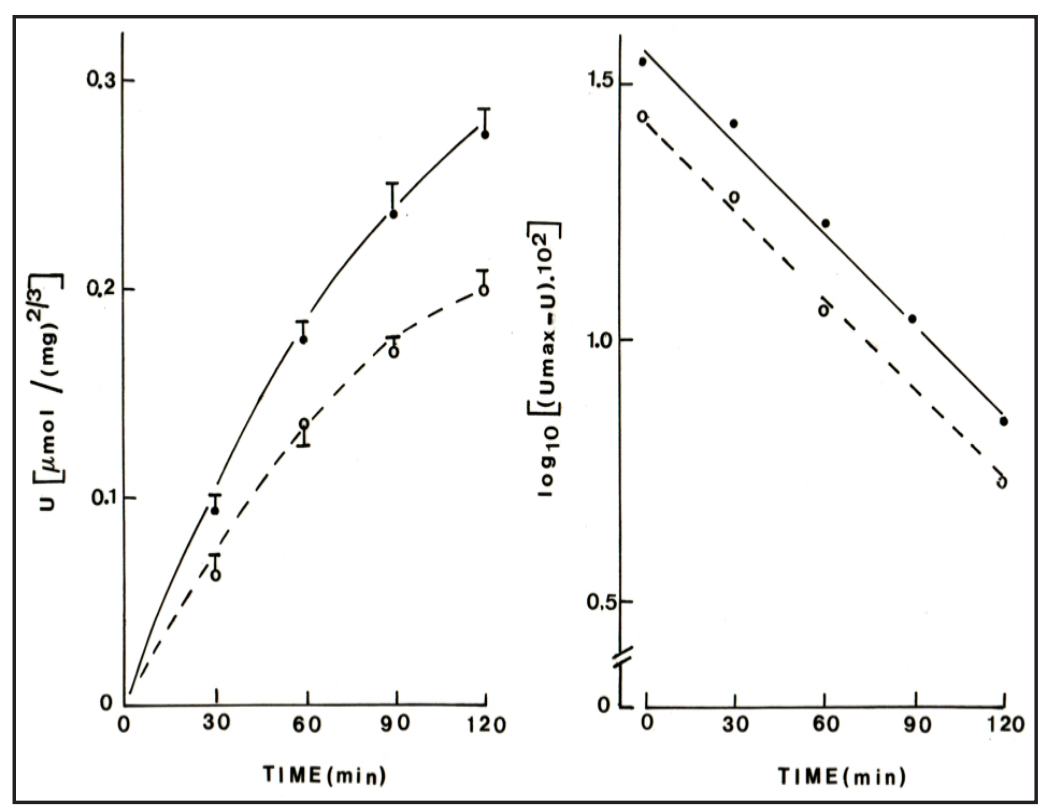

Table 2. Effects of insulin upon the metabolism of D-glucose $(8.3 \mathrm{mM})$ in ductal cells from submandibular salivary gland. a : Results expressed as pmol $/ 10^{3}$ cells per 120 min, $b$ : Paired ratio expressed as a percentage

\begin{tabular}{lccc}
\hline \multicolumn{1}{c}{ Metabolic variable } & ${ }^{14} \mathrm{CO}_{2}$ & ${ }^{3} \mathrm{HOH}$ & ${ }^{14} \mathrm{CO}_{2} /{ }^{3} \mathrm{HOH}^{\mathrm{b}}$ \\
\hline Control (no insulin) & & & \\
Absolute values & $25.7 \pm 1.7(82)^{\mathrm{a}}$ & $339.6 \pm 23.1(77)^{\mathrm{a}}$ & $8.84 \pm 0.65(74)^{\mathrm{b}}$ \\
percent & $100.0 \pm 6.9(14)$ & $100.0 \pm 13.9(15)$ & $100.0 \pm 10.6(12)$ \\
Insulin $(10.0 \mathrm{mU} / \mathrm{ml})$ & & & \\
percent & $92.7 \pm 5.4(15)$ & $95.9 \pm 13.1(15)$ & $104.0 \pm 13.1(13)$ \\
\hline
\end{tabular}

insulin $(10.0 \mathrm{mU} / \mathrm{ml})$. Thus pooling together all available measurements, such a paired ratio averaged in the absence and presence of insulin respectively $67.2 \pm 3.1 \%(n=10)$ and $62.8 \pm$ $5.3 \%(n=9 ; p>0.47)$. The latter two mean values largely exceeded the paired ratio between the distribution space of $\mathrm{L}-\left[1-{ }^{14} \mathrm{C}\right]$ glucose $(1.0 \mathrm{mM})$, used as an extracellular marker, and that of ${ }^{3} \mathrm{HOH}$, such a paired ratio averaging within the same experiments $22.0 \pm 3.1 \%$ (n $=10)$ and $16.4 \pm 2.1 \%(n=8)$ in acinar and ductal cells respectively. Likewise, when the isolated ductal cells were incubated for $120 \mathrm{~min}$ at $8.3 \mathrm{mM}$ D-glucose, no significant effect of insulin $(10.0 \mathrm{mU} / \mathrm{ml})$ upon the oxidation of D-[U- $\left.{ }^{14} \mathrm{C}\right]$ glucose, utilization of $\mathrm{D}-\left[5-{ }^{3} \mathrm{H}\right]$ glucose and paired ratio between these two variables was observed (Table 2).

Further experiments were conducted in ductal rings prepared from submandibular salivary glands and incubated up to $180 \mathrm{~min}$ at an initial D-glucose concentration of 5.6 $\mathrm{mM}$ in either the absence or presence of insulin $(10.0 \mathrm{mU} / \mathrm{ml})$. As already observed in the experiments conducted in hemidiaphragms, the net uptake of D-glucose by the salivary ductal rings did not increase in strict proportion with the length of incubation. This is illustrated in Fig. 9, the curvilinear pattern of the relationship between D-glucose uptake and incubation time, as recorded in the presence of insulin $(10.0 \mathrm{mU} / \mathrm{ml})$ at a D-glucose concentration of $5.6 \mathrm{mM}$, displaying an exponential time course comparable to that shown in Fig. 8. A similar pattern was found when the salivary ductal rings were incubated in the absence of insulin (data not shown). As judged from paired comparisons, the values recorded in the presence of insulin averaged between the $60^{\text {th }}$ and $180^{\text {th }}$ min of incubation $124.4 \pm 4.5 \%(\mathrm{n}=30$; $\mathrm{p}<0.001$ ) of the paired control value found in the absence of insulin (Fig. 9, lower right inset). The mean values derived from such paired comparisons after 60,120 or 180 min incubation did not differ significantly from the just mentioned overall mean value (Fig. 9, lower right panel). Incidentally, even when taking into account the results recorded after only $30 \mathrm{~min}$ of 
Fig. 9. Curvilinear pattern of the time-related uptake of D-glucose (nmol) by ductal rings of submaxillary salivary glands incubated in the presence of insulin $(10.0 \mathrm{mU} / \mathrm{ml})$ at an initial D-glucose concentration of $5.6 \mathrm{mM}$. Mean values $( \pm$ SEM) refer to either 6 (min 30 and 180) or 12 (min 60 and 120) individual measurements. The lower right inset refers to the paired ratio for D-glucose uptake in the presence/absence of insulin after 60, 120 and 180 min incubation, the horizontally shaded area corresponding to the overall mean value $( \pm$ SEM) for the 30 paired comparisons computed between the $60^{\text {th }}$ and $180^{\text {th }}$ min of incubation. The upper left inset refers to the mean absolute values for D-glucose uptake recorded from the $30^{\text {th }}$ to $180^{\text {th }} \mathrm{min}$ of incubation either in the presence of insulin (closed circles and solid line) or in its absence (open circles and dashed line) and illustrated together with the corresponding regression lines.

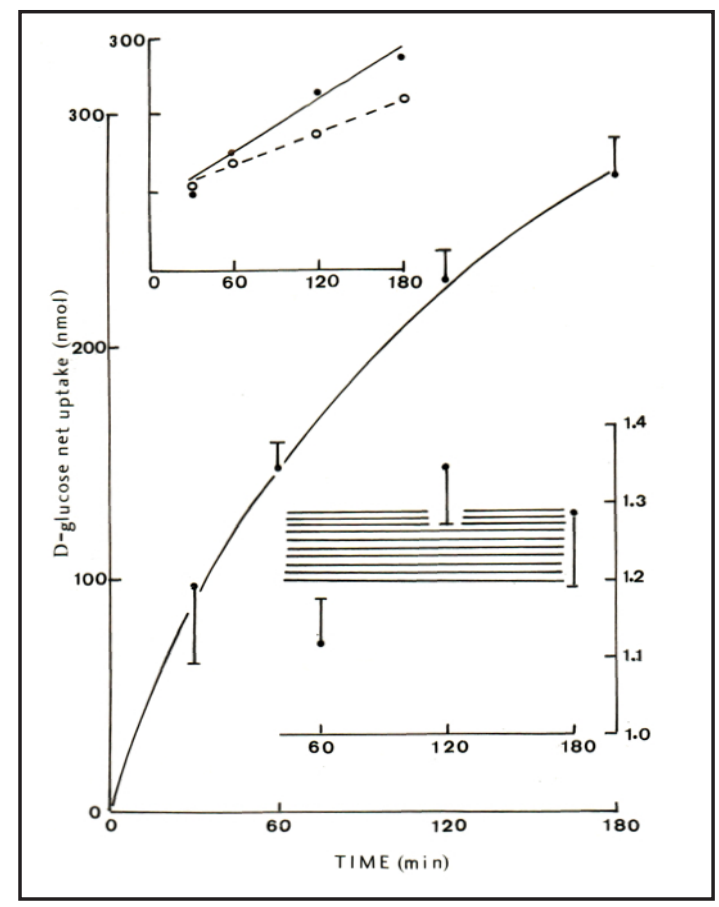

incubation, in which case no significant effect of insulin was observed, the overall mean value for the insulin-induced paired increase in D-glucose uptake remained statistically significant $(p<0.025)$. Moreover, when considering all absolute values for D-glucose uptake from the $30^{\text {th }}$ to $180^{\text {th }}$ min of incubation inclusive, covariance analysis indicated that the slope of the regression line between hexose net uptake and length of incubation was significantly higher $(\mathrm{F}=5.68 ; \mathrm{f}=1,68 ; \mathrm{P}<0.025)$ in the presence of insulin $(+1.20 \mathrm{nmol} / \mathrm{min})$ than in its absence $(+0.71 \mathrm{nmol} / \mathrm{min})$. This is illustrated in the upper left panel of Fig. 9, the time-related increase in D-glucose uptake being highly significant $(\mathrm{p}<0.001)$ whether in the absence or presence of insulin. When computed over the same period of incubation (min 60 to min $120)$, the relative magnitude of the increase in D-glucose uptake caused by insulin (10.0 $\mathrm{mU} / \mathrm{ml}$ ), as judged from paired comparisons, was not significantly different $(\mathrm{p}>0.20)$ in the hemidiaphragms $(+33.7 \pm 6.2 \% ; n=30)$ and salivary ductal rings $(+23.4 \pm 5.3 \%$; $=24)$.

\section{Discussion}

Salivary glucose origin and mechanisms relying on its metabolism in salivary glands are poorly understood. For instance, the biosynthesis of 200 glycoproteins recently identified in the human submandibular and sublingual saliva $[17,18]$ may involve complex metabolic pathways, pointing to the importance of D-glucose uptake and its metabolism in these glands. Mammalian cells transport the glucose via two types of membrane transporter proteins: GLUT family and the $\mathrm{Na}^{+}$/glucose co-transporters, designed as SGLTs.

In the present study, we confirmed the presence of ubiquitous GLUT1 transporter in the submandibular glands of rodents, with basolateral localization, especially in the ductal structures. The transcript level of GLUT1 was similar to that found in lungs, with no genderrelated differences (data not shown).

The major finding of our study is the presence of the facilitative glucose transporter GLUT4 in the submandibular gland in rat and mouse. Until present, GLUT4 was described to be exclusively expressed in skeletal and cardiac muscle and the adipose tissue, where it mediates the insulin-dependent glucose uptake [19]. In our experiments, GLUT4 was detected preponderantly in and nearby the basolateral membrane of ductal cells, suggesting 
that it is rather involved in glucose transport from the blood than in glucose excretion in the primary saliva or ductal re-absorption.

When quantified by RT-qPCR, a difference in mRNA level of GLUT4 in female versus male submandibular has been observed. Located between intercalated ducts and striated ducts, the GCT store-in granules polypeptides such as hormones and growths factors which are secreted into the oral cavity and participate to the regulation of gut mucosa. GCT is preponderant in male and less developed in female rats [20]. This sexual dimorphism is enhanced by testosterone [20]. This could explain why GLUT4 mRNA levels are higher in male gland than in female tissues. The presence of GLUT4 transporter in submandibular gland is not unexpected since insulin and IGF-1 receptors, as well as insulin-signaling pathways have been documented in lacrimal and salivary glands of rats [21]. There is an important immunoreactivity of GLUT4 vesicles in the pillar cells of GCT and cells of striated and intercalated ducts. These cells have been documented to contain a good equipment of calcium-binding proteins [22] witch mediate calcium-signaling pathways and can cross-talk with the regulation of GLUT4 vesicle trafficking and glucose uptake. Due to its preponderant basolateral localization, GLUT4 might function in the submandibular gland to deliver glucose necessary for the energetic needs (proteins synthesis and exocytosis, ions reabsorption) [23]. Western Blot shows the presence of GLUT4 protein in the submandibular glands of rat at the expected molecular weight. Compared to muscle (considered as positive control), its signal looks weak. The risk of contamination in the total protein extract by myoepithelial cells and adipocytes should not be ignored, considering that the submandibular gland is composed of about $60 \%$ of acinar cells, $7 \%$ of striated ducts, $22 \%$ granular duct cells and the remainder as intercalated ducts and myoepithelial cells [24], in fair agreement with previously published data [25-27]. The presence of insulin receptors in rat submandibular glands was already reported [28-30]. The fact documented in the present study that the relative magnitude of the enhancy effect of insulin upon glucose uptake was comparable in ductal rings and hemidiaphragms clearly indicates that such an effect can not be solely attributed to a limited contamination by myoepithelial or adipose cells.

We also detected the SGLT1 co-transporter predominantly expressed in the basolateral membrane of the acinar cells and ductal cells, which confirms the results obtained by others $[4-6,8,22]$. SGLT1 has been described in parotid gland luminal membrane of ductal cells and of some myoepithelial cells $[5,6,8]$ as playing a role in glucose and water reabsorption $[8$, $23,31]$.

The presence of GLUT1, GLUT4 and SGLT1 in ductal cells is compatible with their participation in D-glucose uptake by these cells. Since the oral saliva is hypotonic compared to primary saliva, an important catabolism of D-glucose in ductal cells may be required to cover the energy consumption associated with the reabsorption of ions. As a matter of fact, the catabolism of D-glucose is much higher in ductal cells than in acinar cells (data not shown).

Consistent with our findings on the expression of GLUT4 in ductal cells of the submandibular gland, the experiments conducted in ductal rings unambiguously document that insulin stimulates D-glucose net uptake by these rings. As indicated above, the relative magnitude of such an insulin-induced increase in D-glucose uptake was not significantly lower than that recorded under comparable experimental conditions in rat hemidiaphragms. Incidentally, the use of duct rings rather than isolated ductal cells was motivated by prior findings on such items as the undesirable effect of proteolytic enzymes and limitations encountered in the identification of insulin-binding sites in isolated submaxillary gland cells [28-30].

In conclusion, at least three glucose transporters are expressed in female and male rodent submandibular glands. Our results reveal for the first time the presence of the facilitative glucose transporter GLUT4 specifically localized in the basolateral side of ductal structures, where most likely supports glucose internalization from the bloodstream in order to sustain cellular metabolism. 


\section{Acknowledgements}

This work was supported by a grant from the Belgian Foundation for Scientific Medical Research (grant 3.4520 .07 to A.S.) and by the European Community's Seventh Framework Program FP7/2007-2013 (VIBRANT). We are grateful to Prof. Jean-Pierre Brion for allowing the utilization of the Microscopy Platform, to Prof. Pascale Lybaert and Prof. emeritus André Danguy for guiding advices, and to Gregory Vegh for technical assistance.

\section{References}

1 Mangos JA, Maragos N, McSherry NH: Micropuncture and microperfusion study of glucose excretion in parotid saliva. Am J Physiol 1973;224:1260-1264.

2 Takai N, Yoshida Y, Kakudo Y: Secretion and re-absorption of glucose in rat submandibular and sublingual saliva. J Dent Res 1983;62:1022-1025.

3 Tarpey PS, Wood IS, Shirazi-Beechey SP, Beechey RB: Amino acid sequence and the cellular location of the $\mathrm{Na}^{+}$-dependent D-glucose symporters (SGLT1) in the ovine enterocyte and the parotid acinar cell. Biochem J 1995;312:293-300.

- 4 Balen D, Ljubojevic M, Breljak D, Brzica H, Zlender V, Koepsell H, Sabolic I: Revised immunolocalization of the $\mathrm{Na}^{+} / \mathrm{D}$-glucose cotransporter SGLT1 in rat organs with an improved antibody. Am J Physiol Cell Physiol 2008;295:C475-C489.

-5 Sabino-Silva R, Alves-Wagner AB, Burgi K, Okamoto MM, Alves AS, Lima GA, Freitas HS, Antunes VR, Machado UF: SGLT1 protein expression in plasma membrane of acinar cells correlates with the sympathetic outflow to salivary glands in diabetic and hypertensive rats. Am J Physiol Endocrinol Metab 2010;99:E1028-E1037.

6 Jurysta C, Nicaise C, Cetik S, Louchami K, Malaisse WJ, Sener A: Glucose transport by acinar cells in rat parotid glands. Cell Physiol Biochem 2012;29:325-330.

7 Jurysta C, Nicaise C, Giroix MH, Cetik S, Malaisse WJ, Sener A : Comparison of GLUT1, GLUT2, GLUT4 and SGLT1 mRNA expression in the salivary glands and six other organs of control, streptozotocin-induced and Goto-Kakizaki diabetic rats. Cell Physiol Biochem 2013;31:37-43.

8 Sabino-Silva R, Freitas HS, Lamers ML, Okamoto MM, Santos MF, Machado UF: $\mathrm{Na}^{+}$/glucose cotransporter SGLT1 protein in salivary glands: potential involvement in the diabetes-induced decrease in salivary flow. J Membr Biol 2009;228:63-69.

-9 Dehaye JP, Turner RJ: Isolation and characterization of rat submandibular intralobular ducts. Am J Physiol 1991;261:C490-C496.

10 Malaisse WJ, Franckson JRM: Application des radioisotopes à l'étude de la consommation de glucose par le diaphragme de rat normal. I. Relation entre la taille et l'activité métabolique des diaphragmes. Arch Int Pharmacodyn Ther 1965;153:464-474.

11 Courtois P, Louchami K, Portois L, Chardigny JM, Sener A, Carpentier YS, Malaisse WJ: Effects of a mediumchain triglyceride: fish oil emulsion administered intravenously to omega3 fatty acid-depleted rats on cationic fluxes in aortic rings. Int J Mol Med 2005;16:1089-1093.

12 Malaisse WJ, Maggetto C, Leclercq-Meyer V, Sener A: Interference of glycogenolysis with glycolysis in pancreatic islets from glucose-infused rats. J Clin Invest 1993;91:432-436.

13 Bergmeyer HU, Bernt E: Determination with glucose oxidase and peroxidise; in Bermeyer HU (ed): Methods of Enzymatic analysis. Academic Press Inc. NY, 1994, pp 1205-1215.

14 Lowry OH, Passonneau JV: A flexible system of enzymatic analysis. Academic Press Inc. NY, 1992, pp 174175.

15 Ramirez R, Rasschaert J, Laghmich A, Louchami K, Bakkali Nadi A, Jijakli H, Kadiata MM, Sener A, Malaisse WJ : Uptake of D-mannoheptulose by normal and tumoral islet cells. Int J Mol Med 2001;7:631-638.

16 Malaisse WJ, Sener A: Hexose metabolism in pancreatic islets. Feedback control of D-glucose oxidation by functional events. Biochim Biophys Acta 1988;971:246-254. 


\section{Cellular Physiology $\quad$ Cell Physiol Biochem 2014;33:1149-1161 and Biochemistry \\ Cetik et al.: Glucose Transporters in Ductal Cells}

17 Gonzalez-Begne M, Lu B, Liao L, Xu T, Bedi G, Melvin JE, Yates JR 3rd : Characterization of the human submandibular/sublingual saliva glycoproteome using lectin affinity chromatography coupled to multidimensional protein identification technology. J Proteome Res 2011;10:5031-5046.

-18 Stoeckelhuber M, Scherer EQ Janssen KP, Slotta-Huspenina J, Loeffelbein DJ, Rohleder NH, Nieberler M, Hasler R, Kesting MR: The Human Submandibular Gland: Immunohistochemical Analysis of SNAREs and Cytoskeletal Proteins. J Histochem Cytochem 2012;60:110-120.

-19 Karnieli E, Armoni M: Transcriptional regulation of the insulin-responsive glucose transporter GLUT4 gene: from physiology to pathology. Am J Physiol Endocrinol Metab 2008;295:E38-E45.

-20 Amano O, Mizobe K, Bando Y, Sakiyama K: Anatomy and histology of rodent and human major salivary glands: -overview of the Japan salivary gland society-sponsored workshop. Acta Histochem Cytochem 2012;45:241-250.

21 Rocha EM, de M Lima MH, Carvalho CR, Saad MJ, Velloso LA: Characterization of the insulin-signaling pathway in lacrimal and salivary glands of rats. Curr Eye Res 2000;21:833-842.

-22 Hashimoto J, Jayasinghe N, Kunikata M, Takai Y, Mori M: Immunoreactivity of calmodulin, S-100 protein alpha and beta subunits in rat submandibular glands. Arch Anat Cytol Pathol 1992;40:79-87.

23 Loo DD, Wright EM, Zeuthen T: Water pumps. J Physiol 2002;542:53-60.

24 Quissel DO, Redman RS: Functional characteristics of dispersed rat submandibular cells (tissue dissociation/secretagogue response/receptors/exocrine cells/mucin synthesis). Cell Biology 1979;76:2789-2793.

25 Mangos JA, McSherry NR, Butcher F, Irwin K, Barber T: Dispersed rat parotid acinar cells. I. Morphological and functional characterization. Am J Physiol 1975;229:553-559.

26 Dehaye JP, Turner RJ: Isolation and characterization of rat submandibular intralobular ducts. Am J Physiol 1991;261:C490-C496.

-27 Turner JT, Weisman GA, Camden JM: Upregulation of P2Y2 nucleotide receptors in rat salivary gland cells during short-term culture. Am J Physiol 1997;273:C1100-C1107.

-28 Scacchi GE, Wald MR, Turyn D, Dellacha JM: Effect of proteolytic enzymes on masked insulin receptors in rat submaxillary gland microsomes. Horm Metab Res 1988;20:15-19.

29 Scacchi GE, Turyn D, Dellacha JM: Identification of insulin binding sites in isolated cells from rat submaxillary gland. Arch Biol Med Exp 1988;21:189-193.

30 Turyn D, Scacchi GE, Dellacha JM: Unmasking of insulin receptors in rat submaxillary gland microsomes: effect of high ionic strength, phospholipase C and S-adenosyl-L-methionine. Biochim Biophys Acta 1985;845:333-342.

31 Wright EM, Loo DF, Hirayama BA, Turk E: Surprising versatility of $\mathrm{Na}^{+}$/glucose cotransporters: SLC5. Physiology 2004;19:370-376. 